\title{
Disposal of mouth covers, masks or respirators, after they are used, to minimize the environmental impact and contages by COVID 19
}

\section{Disposición de cubre bocas, mascarillas o respiradores, depués de ser utilizados, para minimizar el impacto ambiental y contagios por COVID 19}

\author{
HERNÁNDEZ-RODRÍGUEZ, María Guadalupe*†, ORTEGA-CHÁVEZ, Laura Antonia，CARO \\ ESCUDERO, Iveth Selene and BARRAZA-ÁLVAREZ, Alberto Guerrero
}

Tecnológico Nacional de México/ Instituto Tecnológico de Chihuahua II.

ID $1^{\text {st }}$ Author: Maria Guadalupe, Hernández-Rodríguez / ORC ID: 0000-0001-7278-7699, Researcher ID Thomson: I6541-2018

ID $1^{\text {st }}$ Co-author: Laura Antonia, Ortega-Chávez / ORC ID: 0000-0001-7860-1277

ID $2^{\text {nd }}$ Co-author: Iveth Selene, Caro-Escudero / ORC ID: 0000-0002-3611-2309

ID $3^{\text {rd }}$ Co-author: Alberto Guerrero, Barraza-Alvárez / ORC ID: 0000-0002-0197-1859

DOI: $10.35429 / J U S D .2021 .21 .7 .24 .33$

Received: July 10, 2021; Accepted October 30, 2021

\begin{abstract}
This article addresses the problem that is being generated by the use of mouth covers, gloves and masks used as protection against covid 19. After more than a year in a pandemic, the demand and waste of these protective implements has increased exponentially, which is why it is necessary to dispose of these sanitary wastes safely, to guarantee community health and the integrity of the environment. On the contrary, improper handling of such a volume of these wastes can have a rebound effect, both on people's health and on the environment. The objective of the research is to properly dispose of these wastes, through the use of special containers for this type of waste, as well as the proposal with the government and companies that use ovens for the production of their products, so that with the necessary measures They could dispose of this type of waste as raw material for their furnaces, since these companies have standards that they comply with to regulate the $\mathrm{Co} 2$ emissions that they emit into the environment, and thus minimize the impact that these wastes bring to the environment.
\end{abstract}

Waste, Environment, Disposal

\section{Resumen}

Este artículo aborda la problemática que se está generando por el uso y disposición de cubrebocas, guantes y mascarillas utilizados como protección contra el covid-19. Tras más de un año en pandemia, la demanda y desechos de estos implementos de protección se ha incrementado en forma exponencial, por lo que es necesario disponer de manera segura de estos desechos sanitarios, para garantizar la salud comunitaria y la integridad del medio ambiente. Por el contrario, el manejo incorrecto de tal volumen de estos desechos, puede ocasionar un efecto de rebote, tanto en la salud de las personas como en el medio ambiente. El objetivo de la investigación es encontrar alternativas para la disposición adecuada de estos desechos, mediante el uso de contenedores especiales para su recolección, así como la propuesta con gobierno y empresas que utilizan hornos en sus procesos de producción, para que con las medidas de seguridad necesarias pudieran disponer de este tipo de materiales, y utilizarlos como combustible para sus hornos, siempre que estas empresas cuenten con controles para el cumplimiento de las normas que regulan las emisiones de $\mathrm{CO} 2$ y otras partículas a la atmósfera, y así minimizar el impacto que estos desechos traen al medio ambiente.

Desechos, Ambiente, Disposición

Citation: HERNÁNDEZ-RODRÍGUEZ, María Guadalupe, ORTEGA-CHÁVEZ, Laura Antonia, CARO ESCUDERO, Iveth Selene and BARRAZA-ÁLVAREZ, Alberto Guerrero. Disposal of mouth covers, masks or respirators, after they are used, to minimize the environmental impact and contages by COVID 19. Journal of Urban and Sustainable Development. 2021. 7-21: 24-33

\footnotetext{
*Correspondence to the author (e-mail: maria.hr@chihuahua2.tecnm.mx)
}

$\uparrow$ Researcher contributing as first author 


\section{Introduction}

In December 2019, there was an epidemic outbreak of pneumonia of unknown cause in Wuhan, China, the rapid spread of the disease prompted the WHO on January 30, 2020, to declare it a health emergency of international concern, based on the impact the virus could have on underdeveloped countries with less health infrastructure. By that date, the disease had been detected in all provinces of mainland China, and cases were diagnosed in 15 other countries. By March 11, the disease was already present in more than 100 countries worldwide, and was recognized as a pandemic by the WHO.

According to available information, the two main routes of transmission of the COVID19 virus are contact and respiratory droplets. These are generated when an infected person coughs or sneezes. Anyone in close proximity (less than one meter) to another person with respiratory symptoms, such as coughing or sneezing, is exposed to these potentially infectious respiratory droplets. In addition, these droplets could be deposited on surfaces where the virus can remain viable, which means that the immediate environment of an infected person can be a source of transmission (contact transmission).

WHO has summarized reports of COVID-19 virus transmission and provided a brief overview of the available evidence of transmission from infected persons, whether symptomatic, presymptomatic or asymptomatic, and has made a series of recommendations on the use of facemasks and other preventive measures to avoid COVID-19 transmission.

The most recommended masks are KN95 masks, which filter 95\% of particles from the environment using static electricity, as well as three-layer surgical masks, which are resistant to fluids and can protect against droplets.

In addition to masks and mouthguards, there has also been a great demand for other protective items such as masks, disinfectant wipes, antibacterial gel, to mention a few, and this has generated an exponential increase of this type of waste, thus generating a great environmental impact, so it is important and necessary to seek strategies that help minimize the impact on the environment.
The UN Environment Program warns that $75 \%$ of the plastics generated in the pandemic will end up in the ocean and estimates that the indirect negative effects of plastic waste for fishing, tourism and maritime transport, add up to $\$ 40$ billion dollars in losses each year.

Given this problem, the research focuses on the importance of disposing of this waste in the most environmentally friendly way, since finding a place for it in the landfill does not contribute to environmental safety and integrity.

Therefore, it is proposed to have special containers for the collection of masks and other protective items, located in various areas of the city, to take them to companies that can use them as fuel for their furnaces, provided that these companies have controls for compliance with the standards that regulate emissions of $\mathrm{CO} 2$ and other particles into the atmosphere, and thus minimize the impact that these wastes bring to the environment.

Therefore, the problem to be solved is to reduce the pollution resulting from the use of mouth covers and other articles to protect against COVID-19, and to use these wastes as fuel for the production furnaces of companies that require it.

\section{Theoretical Framework}

It was from 1890 onwards that the use of face masks began to become common among those engaged in operations. Dr. Guillermo Murillo Godínez, in his brief article Flügge's droplets, explains the following:

1. The droplets reach a distance of one meter, even if spoken in a low voice.

2. They remain in the air for half an hour and then settle on surfaces.

3. They measure up to ten microns. That is, ten millionths of a meter, (Brian Ley demonstrated in 1999 with his study Diameter of a Human Hair that a human hair, however thin it may be, is not less than 17 microns).

4. They are carriers of bacteria and viruses.

HERNÁNDEZ-RODRÍGUEZ, María Guadalupe, ORTEGA-CHÁVEZ, Laura Antonia, CARO ESCUDERO, Iveth Selene and BARRAZA-ÁLVAREZ, Alberto Guerrero. Disposal of mouth covers, masks or respirators, after they are used, to minimize the environmental impact and contages by COVID 19. Journal of Urban and Sustainable Development. 2021 
It was because of this last point that in 1897 the use of surgical masks was advocated in order to protect people from dying from infections after surgery.

The use of mouth covers also helped doctors to face crises such as the 'Chinese plague', an epidemic that emerged in Hong Kong and reached the region of Manchuria in 1910.

During the Spanish flu pandemic in 1918 , the surgical mask became a great ally of doctors and nurses to combat the disease.

At first, the masks had only one or two layers and were sterilized after being used for a certain period of time, until in 1930 Herbert Mellinger, an American doctor, placed a piece of rubber between two layers of gauze to reinforce the safety of the masks and thus prevent the passage of germs.

Although over time the arrival of antibiotics and other medications reduced the use of mouth masks, in 1961 the disposable mask was implemented, which had a more comfortable design that adapted perfectly to the shape of the face.

Today, this garment, which has transcended over the years, has become one of our main allies in the fight against COVID-19.

\section{Mouthpiece or Mask}

It is a resource that serves to ensure the safety of health personnel and patients. Depending on their application, masks are called as follows:

- $\quad$ Surgical or Hygiene Mask.

- $\quad$ Protective Mask or Respirator

\section{Surgical or Hygiene Masks}

When a surgical or hygiene mask is used, the objective is to avoid the transmission of infectious agents to the patient from the health personnel who use it. They are also intended to prevent contact with splashes of potentially pathogenic fluids and blood.
They are designed to prevent the spread of microorganisms that lodge in the mouth, nose and throat, thus avoiding contamination of the patient's wounds, they work from the inside out, the reason why they fulfill their function is because, during exhalation, the air from the nose and mouth comes out with a certain speed and is directed frontally. The particles are relatively coarse, between 3 and 8 microns, (1 micron $=0.001 \mathrm{~mm}$ ), and impact directly on the inside of the mask.

Who should use them:

- $\quad$ People who have any flu symptoms.

- People who live with or take care of a sick person with flu symptoms or other ailment.

- People who need to be in crowded places such as: public transportation, shopping malls, markets, stadiums, churches, elevators, among others.

- In clinical and surgical procedures that require asepsis technique.

- $\quad$ People with flu-like symptoms.

Instructions for use:

- $\quad$ Remove the mouth cover from the bag by taking it from the straps.

- $\quad$ Put it on carefully, covering the mouth and nose; adjust it well to reduce the minimum space between the face and the mouthpiece.

- While wearing it, avoid touching it. If you do touch it, wash your hands or clean them with an alcohol-based gel cleanser.

- Every time the mouthpiece gets wet, change it.

- $\quad$ Do not share it, it is for personal use.

- Do not reuse it.

- $\quad$ Change it when it is broken or worn out.

- Throw it away after visiting a sick person in the hospital.

How to dispose of it:

- $\quad$ Once used, destroy and throw the mouth cover immediately into the garbage can or plastic bag, tie it and throw it into the garbage can.

Wash hands immediately with soap and water, applying the correct technique. 
- In a hospital, dispose of it in the designated containers.

Do not leave the mouth cover on the table, bureau, desk or any other surface to avoid contamination.

\section{Protective Mask or Respirator}

This mask is used when what is required is to protect health personnel from the inhalation of environmental contaminants, such as biological hazards, drugs, cytostatics, among others. They are designed to work from the outside in, since, when inhaling, the air velocity is lower and is distributed uniformly across the entire surface of the mask, the filtration is produced thanks to several mechanisms such as; diffusion, interception, inertia and electrostatic charge. The risk of penetration depends on the size of the particle, these masks trap up to 0.6 microns.

In these masks the facial adjustment is fundamental for the effectiveness of protection, the possible leaks by the edges of the mask have an important effect, since the air can pass towards the interior of the mask and the smaller the particles are, such as those of laser smoke that measure 1 micron, the greater the risk.

Experimental data indicate that, if a surgical mask is used for the purpose of protecting the user from inhaling particles, the air inside the mask is between 1.5 and 3 times cleaner than the air outside. Measurements carried out in the same way, but with a protective mask, show that the air inside is between 4 and 50 times cleaner than the air outside, so it is clear that when it comes to protecting the user, the effective alternative is the respirator.

Before being marketed, respirators must be tested in a notified laboratory to ensure that they meet basic safety requirements, using a test procedure of the European Harmonized Standard for Respiratory Protection Equipment; EN149, which establishes different categories FFP1, FFP2 and FFP3, the latter being the maximum protection level, the test evaluates the effectiveness of the filter and the facial adjustment.
The selection of the mask depends on the toxicity or hazardousness of the material, the environmental concentration and the exposure time. In the case of microorganisms, the epidemiology and the ease of treatment or cure of the disease must be taken into account. For example, in the case of tuberculosis, and due to the appearance of resistant strains, the recommended protection is FFP3.

\section{Use and Positioning}

- $\quad$ Place the respirator over your hand so that it covers your fingertips with the nose clip, allowing the elastic bands to hang freely under your hand.

- $\quad$ Place the respirator under your chin with the nose clip facing up.

- $\quad$ Pull the lower elastic band over your head and place it around your neck, under your ears Take the upper elastic band and pull it over your head to place it at the back, on top of your head.

- If the respirator becomes damaged, soiled or difficult to breathe through, immediately leave the contaminated area and replace the respirator. This is a symptom that the respirator is saturated, and can be a cause of illness or death.

- This respirator can help reduce inhalation exposure to certain types of biological particles, e.g., molds, Bacillus anthracis, Mycobacterium tuberculosis, among others, but it cannot eliminate the risk of disease or infection.

- $\quad$ Using the fingers of both hands, mold the clip to fit the shape of your nose by pushing inward while moving your fingertips down both sides of the nose clip. Squeezing (pinching) the nose clip with one hand may cause improper fit and reduced respirator effectiveness.

- $\quad$ To check the fit of the respirator, place both hands on the respirator and exhale sharply. If air comes out around the nose, readjust the respirator.

\section{Most commonly used types of respirators}

The Centers for Disease Control and Prevention (CDC) now recommends that all citizens wear a facemask as a protective measure, but with so many options available it can be confusing to know which is best for everyday use. 
The facemasks needed by doctors and first responders are different from the ones someone should wear when going to the grocery store, and it's important to understand the difference. So what is an N95 mask and how is it different from a surgical mask? Is a cloth mask safe?

\section{N95 Respirators}

N95 respirators, technically considered respirators, are named for their ability to filter out $95 \%$ of ambient particles using static electricity. To ensure their safety and effectiveness, all N95s must be tested and approved by the National Institute for Occupational Safety and Health (NIOSH).

Unlike other forms of respirators, N95s are fitted and must be tested for each individual. Once properly fitted, the mask should fit snugly and create a seal against the skin with minimal leakage, which makes it very safe but can also be uncomfortable.

Static electricity coupled with the custom fit and minimal leaks make the N95 mask an extremely effective option. "N95s are critical supplies that are primarily recommended for healthcare workers and other first responders."

N95s are vital to protecting healthcare workers who provide direct patient care. Not only are they in very close contact with patients, but they often perform proceduressuch as intubating ventilators-that increase the risk of infection by generating large amounts of aerosol particles.

Prior to COVID-19, N95s were typically used for patients with highly infectious respiratory diseases, such as tuberculosis, and these masks were discarded after each patient visit. Now, N95s are so scarce that clinicians must wear their respirator during their shift and decontaminate it for reuse.

At Mass General and throughout Mass General Brigham HealthCare systems, the N95s are being decontaminated using a machine that generates vaporized hydrogen peroxide.

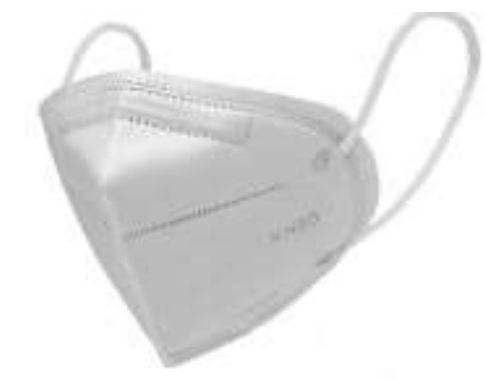

Figure 1 Mask N95 Unimat innovation on surfaces

\section{Surgical masks}

Surgical masks are the most commonly used surgical masks in Mass General. "The benefit of the surgical mask is that it is fluid-resistant and can protect you against large drops or splashes of body fluids. Also, it does not require fit testing."

Unlike N95s, surgical masks do not protect against aerosols and are not sufficient protection when in direct contact with COVID patients during aerosol-generating procedures.

Surgical masks are an extremely valuable piece of PPE (personal protective equipment) within the current COVID-19 pandemic. At Massachusetts General Hospital, each person is required to wear a surgical mask upon entering the hospital because it can help trap droplets and prevent the spread of disease when the mask wearer coughs or sneezes. It can also protect personnel from exposure to asymptomatic personnel or patients who may not have been identified as COVID-19 carriers. The mask must be discarded upon exit, which means that maintaining a sufficient supply is crucial for these facilities.

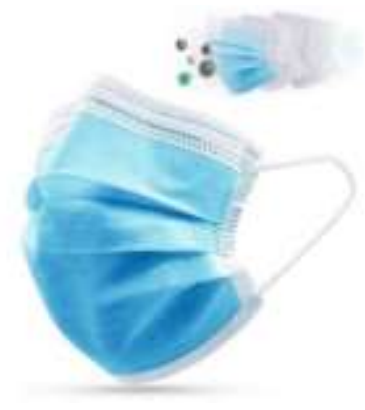

Figure 2 Surgical mask Elements of protection.com

\section{Cloth Facemasks}

CDC continues to recommend that the general public wear cloth facemasks in public places to slow the spread of COVID-19. 
While they may not protect against aerosols, if the CDC's recommendations for mitigating the spread of the disease - staying home, reducing unnecessary travel and keeping six feet of physical distance - are practiced, the level of protection provided by a cloth mask is sufficient.

"The chance of becoming infected through aerosols in public is so low [due to the amount of open space] that a cloth mask is sufficient to prevent it."
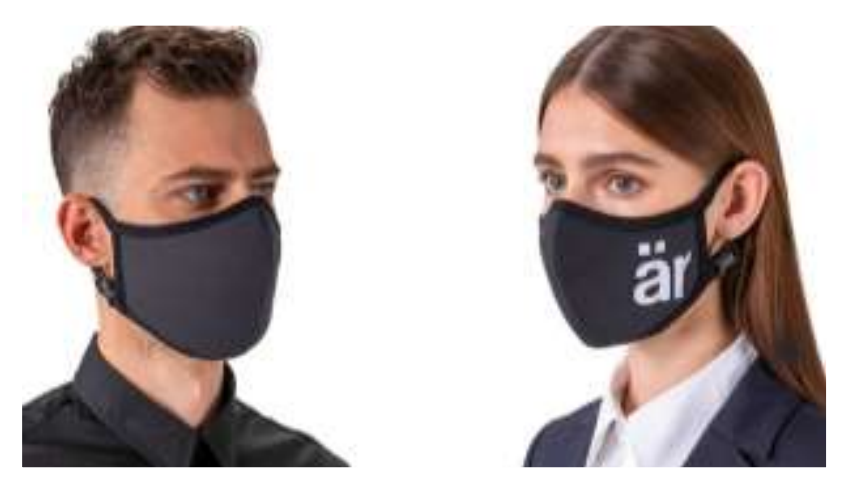

Figure 3 Fabric mask arfacemask.com

\section{Proper Disposal of Masks and Respirators}

During the pandemic, the use of face masks has been a key health measure to prevent the transmission of COVID-19, however, these types of masks take more than 450 years to disintegrate and in many cases end up in landfills, rivers and oceans.

According to the World Health Organization (WHO), masks should be disposed of in a closed garbage container immediately after use and should not be reused, as factors such as humidity and secretions shorten their useful life. In health centers, these surgical materials should be treated as medical waste and disposed of in red bags.

Currently, many people leave the masks on the streets instead of putting them in industrial waste containers, which causes pollution in rivers and seas. Laurent Lombard, co-founder of the NGO Operation Clean Sea, mentions that it is best to put the masks in a plastic bag before throwing them in closed cans to prevent animals from opening them and the wind from carrying them to other places.
Thanks to their manufacturing components such as polypropylene, mouth covers are difficult to degrade. As biohazardous materials, placing them in the recycling section puts the health of garbage collectors and other recycling workers at risk.

In this sense, garbage collectors are an essential link because they have direct contact with contaminated materials. They are the first line of defense so that personal protective equipment does not end up in rivers and seas. Improving our practices in the disposal process would translate into healthier ecosystems.

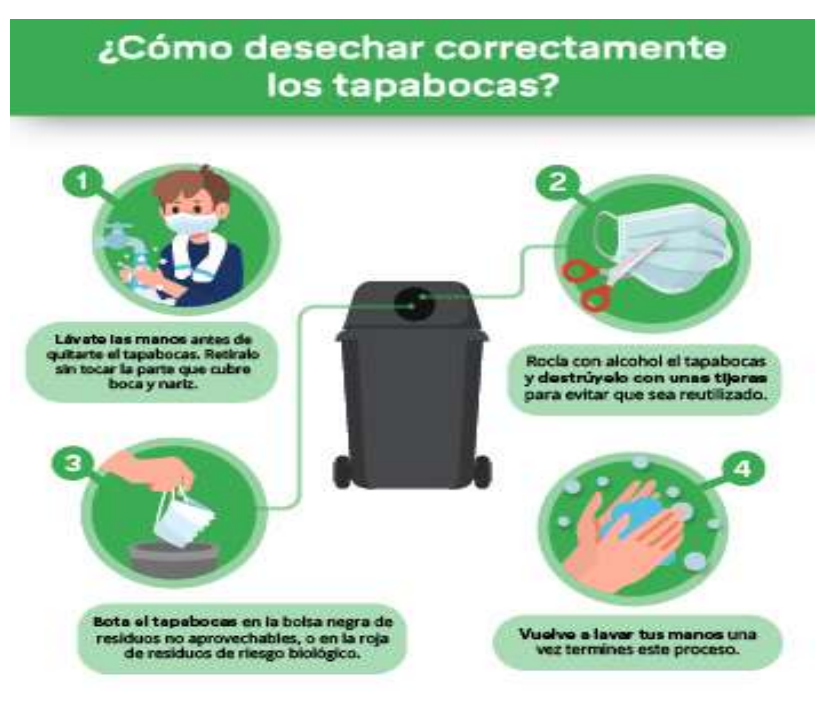

Figure 4 Disposal of face masks Ean University

\section{Best practices for disposing of face masks}

To preserve everyone's health, it is recommended to dispose of the face mask as follows:

1. Destroy the mouth cover with scissors and place the pieces in a knotted plastic bag.

2. Spray the bag with chlorine solution.

3. Wash hands and disinfect scissors after inserting the mask into the bag.

4. Do not dispose of masks on public roads.

5. In case you have a cloth mask, wash and disinfect it after each use.

As citizens we have the responsibility to take care of our health and that of our loved ones, thus avoiding the spread of the coronavirus. 


\section{Containers for the exclusive use of mouth covers}

Once the practices for disposing of masks or mouth masks are recognized, it is necessary to place them in a special container, in order to dispose of them properly, and thus reduce contamination by this type of material, as well as COVID-19 infections.

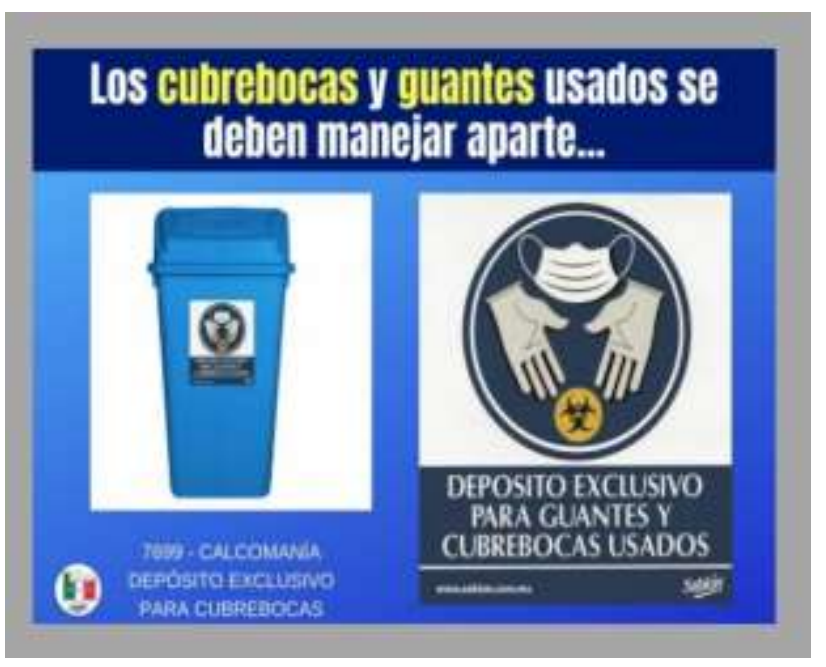

Figure 5 Container for used mouthpieces. Sablon

\section{Large industries that use kilns in their production}

In order to carry out this project, it is necessary to establish agreements with companies that use kilns in their production and that are well regulated in terms of environmental emissions.

Among the companies known to use industrial kilns for their production are cement companies, as well as producers of flooring and ceramics, which are looking for alternative fuels for their kilns.

The high temperatures used by cement kilns in the clinkerization process (1200 $1450^{\circ} \mathrm{C}$ ) make them an excellent option for burning industrial waste (plastics, paper, textiles, etc.) and biomass (wood, sawdust, nut shells, etc.), which helps prevent these wastes from reaching sanitary landfills and at the same time takes advantage of the calorific value they generate.

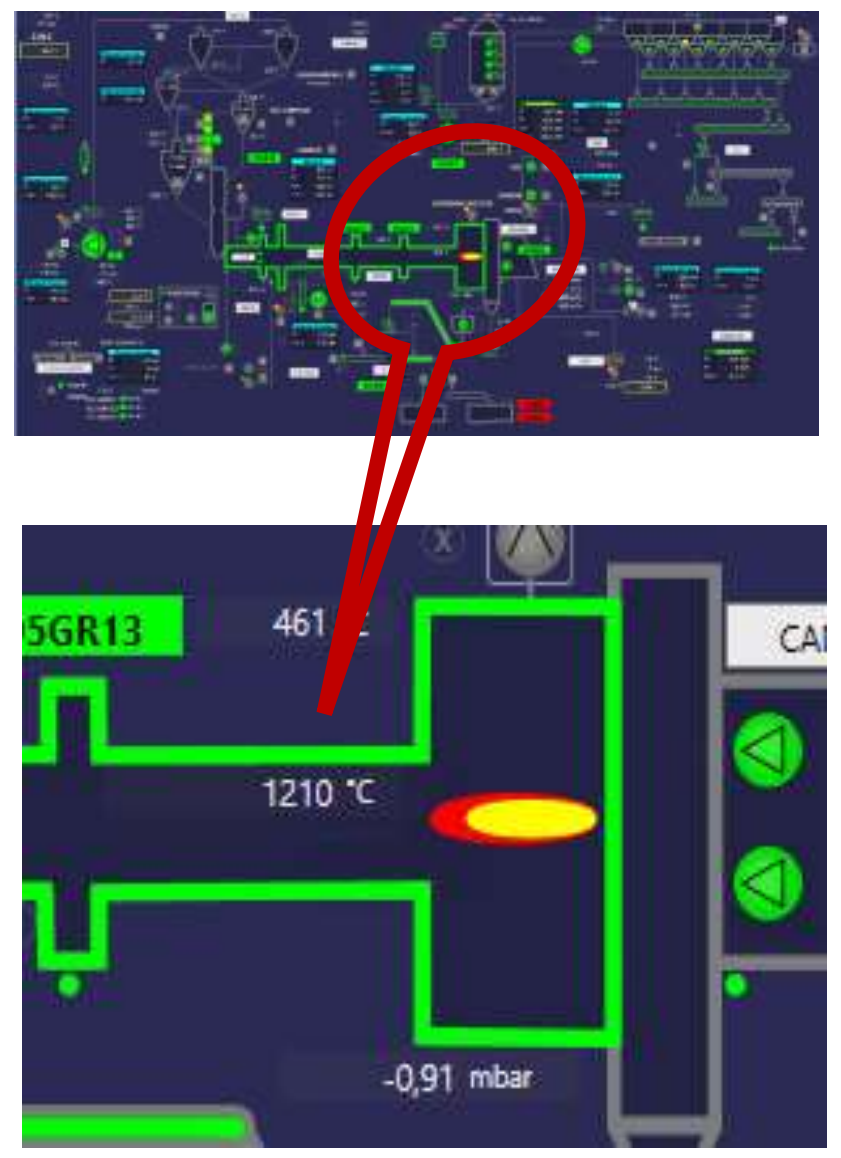

Figure 6 Operating screen mimic, furnace temperature analyzer. Taken from own image

In order to carry out this process of replacing coal (primary or main fuel) with alternative fuels (those mentioned above), it is necessary to characterize the materials that will be introduced into the combustion process, which consider the content of chlorine and sulfur among the main components, since these can generate instability in the furnace process.

Since the material from which the ventilators are made does not contain these compounds, it is possible to use them as an alternative fuel.

One of the control variables in the combustion processes is the emission of gases into the atmosphere, being $\mathrm{CO}$ (carbon monoxide) the most representative, which is continuously monitored by means of a gas analyzer, which continuously measures the content of CO, NOx (nitrogen oxides), Sox (sulfur oxides) and oxygen present in the combustion gases. Keeping the oxygen content in the gases above $2 \%$ ensures a good combustion process. 


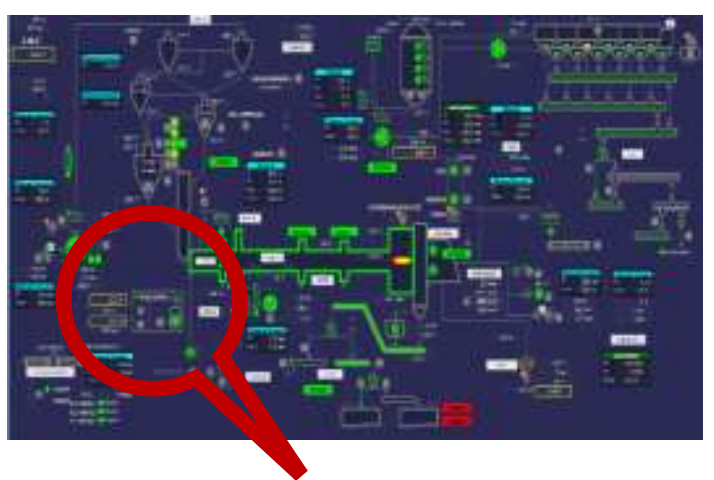

Oxygen content

Content of $\mathrm{CO}$

Content of NOx

Content of SOx

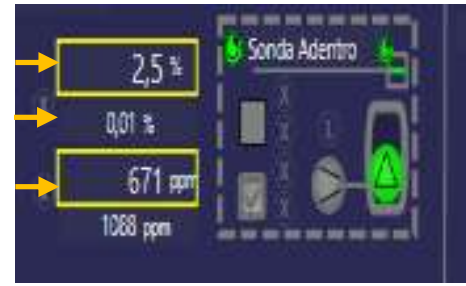

Figure 7 Operating screen mimic, gas analyzer. Own image taken

To analyze the expected benefits of disposing of the used respirators to be used as alternative fuel, a measurement of the unit weight was made using a precision scale, obtaining a weight of 4.83 grams per piece.

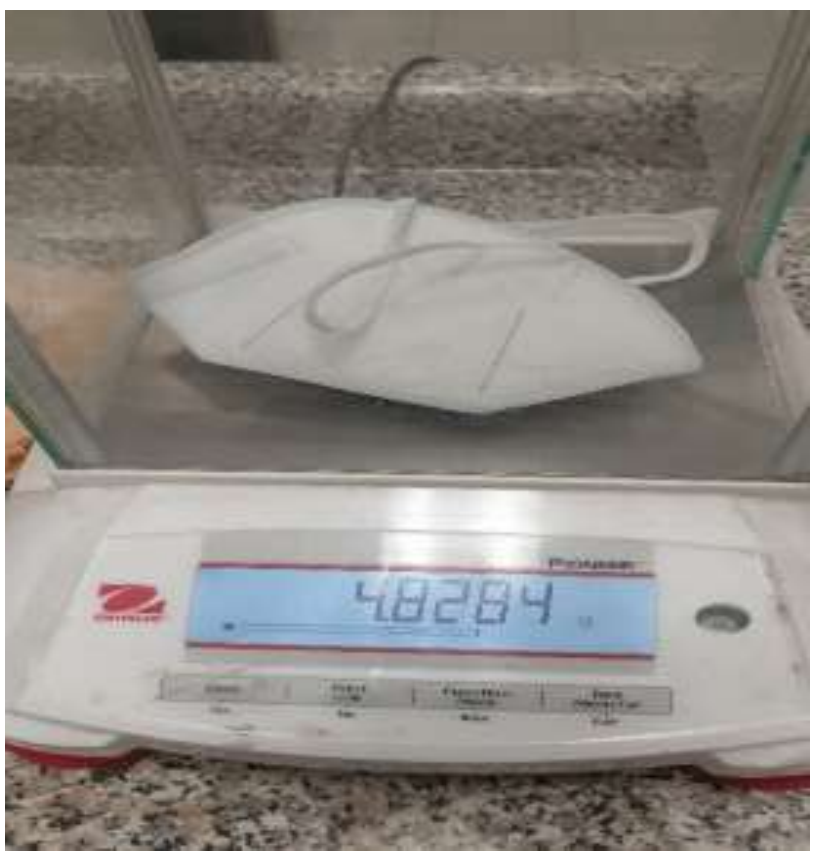

Figure 8 Weighing of N95 respirator. Taken from own image

Subsequently, the calorific value of the material from which a ventilator is made is determined. This is done using a Leco model AC500 calorimeter, which yielded a result of $13,596.5 \mathrm{BTU} / \mathrm{lb}(7,559.68 \mathrm{Kcal} / \mathrm{Kg})$, which is slightly higher than that of the bituminous coal used as primary fuel $(12,150 \mathrm{BTU} / \mathrm{lb}$ or 6,756 $\mathrm{Kcl} / \mathrm{Kg}$ ). This result shows that 1 ton of rebreathers is equivalent to 1.12 tons of coal.

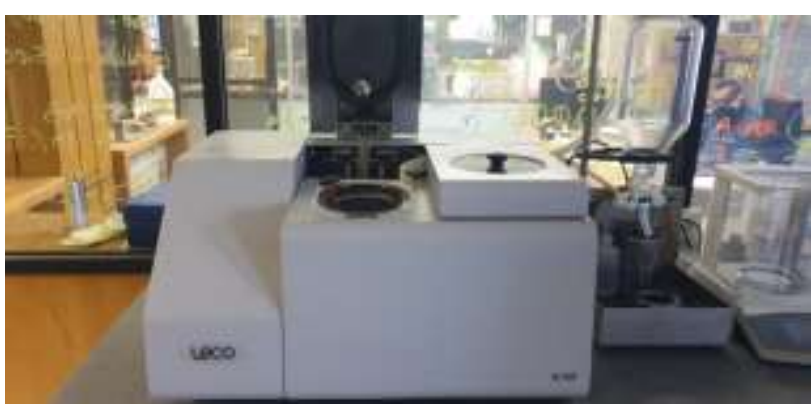

Figure 9 Leco Calorimeter model AC500, taken from own image

The current approximate cost of coal is $\operatorname{mxp} \$ 2,160.00$, so replacing it with one ton of respirators would result in a partial savings of $\operatorname{mxp} \$ 2,419.20$ (due to the factor of 1.12).

It is estimated a cost for handling and shredding the respirator (it must be reduced to a size that optimizes its combustion in the burner) of mxp\$625.00/ton, this for collection, electric energy, shredding, transportation and labor) so the benefit per ton of respirator co-processed as an alternative fuel is $\operatorname{mxp} \$ 1,794.20$. To obtain 1 ton of respirators, it is necessary to collect 207,040 pieces. The population in the main cities of the state of Chihuahua is:

$\begin{array}{lr}\text { Cd. Juárez } & 1,500,000 \\ \text { Chihuahua } & 926,000 \\ \text { Cuauhtémoc } & 180,000 \\ \text { Delicias } & 152,000 \\ \text { Total } & 2,758,000\end{array}$

If it is estimated that on average each inhabitant generates 4 used respirators per month, and only $50 \%$ of them are recovered to be co-processed to generate energy, we obtain 5,516,000 pieces, which means 26.64 tons, which would provide a savings of $\operatorname{mxp} \$ 47,801.43$ per month, and $\operatorname{mxp} \$ 573,617.11$ per year.

\section{Main regulations regarding waste management and emissions}

The following are the main laws and regulations governing waste management and emissions produced by the burning of materials:

Ley General del Equilibrio Ecológico y Protección al Ambiente (LGEEPA) Establishes general provisions regarding waste.

HERNÁNDEZ-RODRÍGUEZ, María Guadalupe, ORTEGA-CHÁVEZ, Laura Antonia, CARO ESCUDERO, Iveth Selene and BARRAZA-ÁLVAREZ, Alberto Guerrero. Disposal of mouth covers, masks or respirators, after they are used, to minimize the environmental impact and contages by COVID 19. Journal of Urban and Sustainable Development. 2021 
Ley del Equilibrio Ecológico y Protección al Ambiente del Estado de Chihuahua (LGEEPA CH) Establishes general provisions regarding waste of state application.

General Law for the Prevention and Integral Management of Waste (LGPGIR) General regulation, includes 3 categories of hazardous waste, urban solid waste and special handling waste.

Regulation of the General Law for the Prevention and Integral Management of Waste (RLGPGIR).

Law for the Prevention and Integral Management of Waste of the State of Chihuahua (LGPGIR CH) Regulates urban solid waste and special handling waste.

Regulation of the Law for the Prevention and Integral Management of Waste of the State of Chihuahua (RLGPGIR CH).

NOM-052-SEMARNAT-93. Establishes characteristics of Hazardous Waste.

NOM-052-SEMARNAT-93 Establishes methods for the determination of hazardous waste.

NOM-054-SEMARNAT-93. Procedure to establish incompatibility between two or more hazardous wastes.

NOM-087-SEMARNAT- SSA1-2002 Biological Infectious Waste, classification and handling specifications.

NOM-161-SEMARNAT-2011 Special Management Waste, classification and management plans.

\section{Regarding emissions:}

Ley General del Equilibrio Ecológico y Protección al Ambiente (LGEEPA) Establishes general provisions regarding emissions.

Law of Ecological Balance and Environmental Protection of the State of Chihuahua (LGEEPA CH) Establishes general provisions regarding emissions of state application.
Regulation of the General Law of Ecological Balance and Environmental Protection regarding the prevention and control of air pollution (RLGEEPA PCCA) Establishes more specific requirements regarding fixed sources under federal jurisdiction.

NOM-085-SEMARNAT-2011, Air Pollution-Maximum permissible emission levels of indirect heating combustion equipment and their measurement.

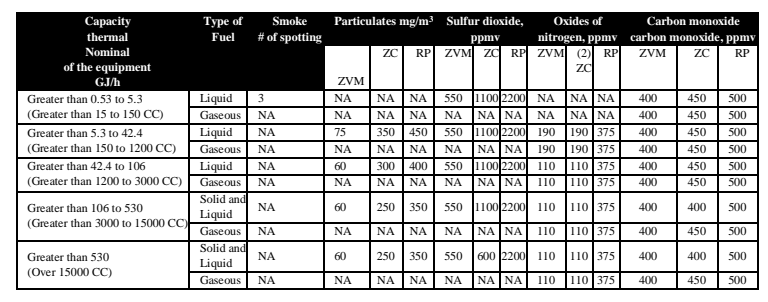

Table 1 Maximum permissible emission levels for existing equipment at the time the NOM came into force. (Boilers, steam generators, thermal oil heaters or other types of fluids, and indirect heating ovens and dryers. NOM-085-SEMARNAT-2011

$\mathrm{ZMCM}=\mathrm{CDMX}$ metropolitan zone.

$\mathrm{ZC}=$ Critical zones (borders and large metropolitan zones such as GDL, MTY, among others).

$\mathrm{RP}=$ Rest of the country

\section{NOM-040-SEMARNAT-2002.}

Maximum permissible levels of atmospheric emissions for the manufacture of cement and establishes several compliance tables:

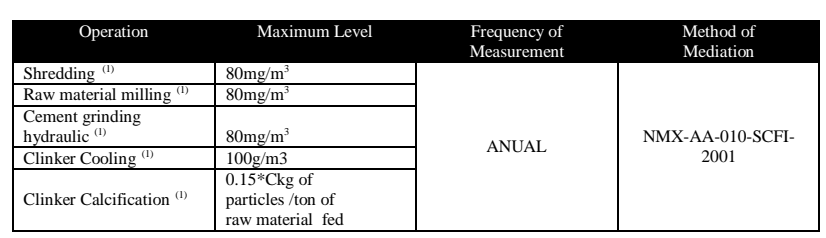

Table 2 Maximum permissible levels of particulate emissions. NOM-040-SEMARNAT-2002

\begin{tabular}{|c|c|c|c|c|c|c|c|c|}
\hline Parameter & & te cem & & & $\begin{array}{l}\mathrm{ycem} \\
\mathrm{ug} / \mathrm{m}^{3}\end{array}$ & & $\begin{array}{l}\text { Frequency of } \\
\text { measurement }\end{array}$ & $\begin{array}{l}\text { Iethod or principle } \\
\text { of measurement }\end{array}$ \\
\hline Sulfur dioxide sulfur & 400 & 2200 & 2500 & 400 & 800 & 1200 & & NMX-AA-055- \\
\hline $\begin{array}{l}\text { Nitrogen oxide nitrogen ox } \\
(2)\end{array}$ & 800 & 1400 & 1600 & 800 & 1000 & 1200 & & \\
\hline $\begin{array}{l}\text { Carbon monoxide arbon } \\
\text { monoxide }\end{array}$ & 3000 & 3500 & 4000 & 3000 & 3500 & 4000 & & sive \\
\hline
\end{tabular}

Table 3 Maximum permissible levels of gas emissions. NOM-040-SEMARNAT-2002

Subject to validation * Maximum total substitution at any time based on the calorific value of the conventional fuel.

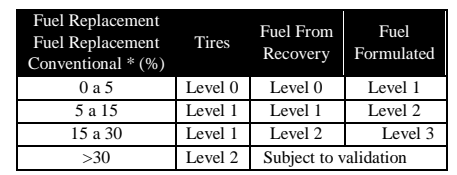

Table 4 Level of Compliance, Type and Volume of Substitution Fuel. NOM-040-SEMARNAT-2002

HERNÁNDEZ-RODRÍGUEZ, María Guadalupe, ORTEGA-CHÁVEZ, Laura Antonia, CARO ESCUDERO, Iveth Selene and BARRAZA-ÁLVAREZ, Alberto Guerrero. Disposal of mouth covers, masks or respirators, after they are used, to minimize the environmental impact and contages by COVID 19. Journal of Urban and Sustainable Development. 2021 


\begin{tabular}{|c|c|c|c|c|}
\hline Parameter & $\begin{array}{l}\text { Emission } \\
\mathrm{Mg} / \mathrm{m}^{3}\end{array}$ & $\begin{array}{l}\text { Frequency of } \\
\text { Nivel } 2 \\
\end{array}$ & $\frac{\text { Measurement }}{\text { Nivel3 }}$ & Method or principle of measurement \\
\hline $\mathrm{CO}^{(2)}$ & Table 2 & Annual & & $\begin{array}{l}\text { Infrarrojo no dispersivo } \\
\text { NMX-AA-035-1976 }\end{array}$ \\
\hline $\mathrm{HCI}$ & 70 & Semiannual & Continuo & $\begin{array}{l}\text { Infrarrojo no dispersivo } \\
\text { NMX-AA-070-1980 }\end{array}$ \\
\hline $\mathrm{Nox}^{(2)}$ & Table 2 & Annual & Continuo & Quimiluminisencia \\
\hline $\mathrm{SO}_{2}^{(2)}$ & Table 2 & Annual & Continuo & $\begin{array}{l}\text { Infrarrojo no dispersivo } \\
\text { NMX-AA-070-1980 }\end{array}$ \\
\hline $\mathrm{HCt}\left(\right.$ as $\left.\mathrm{CH}_{4}\right)$ & 70 & Semiannual & Continuo & Ionización de flama \\
\hline Particles & $\begin{array}{ll}\text { Table } 1 \\
\end{array}$ & Annual & Annual & Isocinético NMX-AA-10-2001 \\
\hline $\mathrm{Sb}, \mathrm{As}, \mathrm{Se}, \mathrm{Ni}, \mathrm{Mr}$ & $0.7^{(3)}$ & Annual & Semiannual & \multirow{4}{*}{$\begin{array}{l}\text { Atomic absorption spectrometry or } \\
\text { equivalent }\end{array}$} \\
\hline $\mathrm{Cd}$ & 0.07 & Annual & Semiannual & \\
\hline $\mathrm{Hg}$ & 0.07 & Annual & Semiannual & \\
\hline $\mathrm{Pb}, \mathrm{Cr}, \mathrm{Zn}$ & $0.7^{(3)}$ & Annual & Semiannual & \\
\hline $\begin{array}{l}\text { Dioxins and } \\
\text { furans }\end{array}$ & $0.2\left(\mathrm{ng} \mathrm{EQT} / \mathrm{m}^{3}\right.$ & Biennial & Annual & $\begin{array}{l}\text { High resolution gas chromatography coupled } \\
\text { to } \\
\text { coupled to high resolution } \\
\text { high resolution gas chromatography coupled } \\
\text { to } \\
\text { mass spectrometry }\end{array}$ \\
\hline
\end{tabular}

Table 5 Maximum Permissible Levels of Emissions to the Atmosphere. NOM-040-SEMARNAT-2002

(1) All values refer to normal dry conditions, corrected to $7 \%$ oxygen $(\mathrm{O} 2)$ by volume.

(2) According to the location of the facility.

(3) Total sum of heavy metals.

SEMARNAT has several procedures for the authorization of atmospheric emissions:

SEMARNAT-07-033-C - Recycling or coprocessing of hazardous waste.

SEMARNAT-07-033-F - Hazardous waste incineration.

\section{Conclusions}

According to the analysis carried out, it can be seen that by carrying out the project we expect a reduction in pollution due to the disposal of masks and respirators, thus contributing to help the environment, since at least $5,516,000$ pieces would be collected per year to be co-processed to generate energy, which would mean a savings of MXP\$573,617.11 per year in fuel for the furnace of the company that decides to implement this project.

\section{Referencias}

AXA México. (2020). COVID-19 sin contaminación: desecha tu cubrebocas de forma correcta. axa.mx. https://axa.mx/blogs/blog-axa/covid-19-sincontaminacion-desecha-tu-cubrebocas-deforma-correcta
Leyva, R. G. (2009). El cubre bocas ó mascarilla, un recurso para garantizar la seguridad del personal de salud y del paciente. Enfermería Universitaria. https://www.medigraphic.com/cgibin/new/resumen.cgi?IDARTICULO=37501

Massachusetts General Hospital. (2020). La diferencia entre las mascarillas N95, las mascarillas quirúrgicas y las mascarillas de tela.

https://www.massgeneral.org/es/coronavirus/ladiferencia-entre-las-mascarillas-N95-lasmascarillas-quirurgicas-y-las-mascarillas-detela

Organización Mundial de la Salud (OMS). (2020). Cronología de la respuesta de la OMS a la COVID-19. who.int. https://www.who.int/es/news/item/29-06-2020covidtimeline

SEMARNAT. (2011). NORMA Oficial Mexicana NOM-085-SEMARNAT-2011, Contaminación atmosférica-Niveles máximos permisibles de emisión de los equipos de combustión de calentamiento indirecto y su medición. Diario Oficial de la Federación. http://www.dof.gob.mx/normasOficiales/4632/s emarnat/semarnat.htm

SEMARNAT. (2002). NORMA Oficial Mexicana NOM-040-SEMARNAT-2002, Protección ambiental-Fabricación de cemento hidráulico-Niveles máximos permisibles. Diario Oficial de la Federación. http://siga.jalisco.gob.mx/assets/documentos/no rmatividad/nom040semarnat2002.htm

Tiempo, M. E. E. (2020). Así nació el cubrebocas. El Universal. https://www.eluniversal.com.mx/opinion/mochi lazo-en-el-tiempo/asi-nacio-el-cubrebocas

Torreón.-, S. E. G. E. D. E. (2020). Este es el origen del cubrebocas. El Siglo. https://www.elsiglodetorreon.com.mx/noticia/1 724109.este-es-el-origen-del-cubrebocas.html T. (2020b). Que es un cubrebocas y para qué sirve. Tecnomedicina. https://www.tecnomedicina.mx/que-es-uncubrebocas-y-para-que-sirve/ 